\title{
Between Form and Substance
}

\section{ANDREW ROBERTSON AND JAMES GOUDKAMP}

This collection of essays is drawn from the Ninth Biennial Conference on the Law of Obligations, which was focused on the theme of this book. The theme was inspired by PS Atiyah and Robert Summers' influential comparative study Form and Substance in Anglo-American Law, which was published a little over 30 years ago. ${ }^{1}$ Atiyah and Summers explored the relationship between formal reasoning (the application of rules without reference either to the justifications that underlie the rules being applied, or to other potentially relevant considerations of justice or welfare) and substantive reasoning (direct reference to considerations of justice, purpose, welfare or convenience). Duncan Kennedy was also concerned with form and substance in this sense in his landmark article 'Form and Substance in Private Law Adjudication', which preceded Atiyah and Summers' study. ${ }^{2}$ Kennedy argued that a lawmaker's choice of form correlates with a substantive preference, with individualism corresponding with a preference for rules and altruism with a preference for standards. Form and substance are also distinguished in various other ways in the law of obligations. A form and substance dichotomy that is more familiar to private lawyers in the common law world is the distinction between what might broadly be described as appearance on the one hand and underlying truth on the other. In this vein, distinctions are commonly drawn between the form of a legal instrument, transaction or relationship, and its intended or actual legal effect. A related distinction is sometimes drawn between the form of a legal or equitable doctrine and its substantive effect. This book explores the insights provided by various manifestations of the form and substance dichotomy. ${ }^{3}$

The primary purpose of Atiyah and Summers' analysis of form and substance was comparative. They claimed that a profound difference - perhaps the most

\footnotetext{
${ }^{1}$ PS Atiyah and RS Summers, Form and Substance in Anglo-American Law: A Comparative Study of Legal Reasoning, Legal Theory, and Legal Institutions (Oxford, Clarendon Press, 1987).

${ }^{2}$ D Kennedy, 'Form and Substance in Private Law Adjudication' (1976) 89 Harvard Law Review 1685.

${ }^{3} \mathrm{~K}$ Barker, 'Form and Substance: Three Observations on the State of Debate', this volume, ch 18, text accompanying nn 5-9, identifies no fewer than 13 different kinds of distinction between form and substance.
} 


\section{Andrew Robertson and James Goudkamp}

profound difference - between the English legal system and those of the US was that the English approach to law was highly formal, while the American was more focused on and driven by matters of substance, in each case excessively so. Atiyah and Summers helpfully captured their thesis in the idea of contrasting 'visions' of law, with the English vision of law being essentially that of 'a system of rules', while the American vision of law was of 'an outward expression of the community's sense of right or justice. ${ }^{3}$

The differences between English and American approaches to law, Atiyah and Summers showed, have deep roots. The English understanding of law has long been dominated by Austinian positivism, while the American long influenced by notions of natural law and of law as an instrument of social and economic policy. ${ }^{5}$ Atiyah and Summers suggested that those different conceptions of law and the respective levels of formality in legal reasoning both influenced, and were influenced by, wide ranging differences in legal education, legal scholarship, the conception of legal rules, the doctrine of precedent, the capacity of the courts to develop and reform the common law, the legislative process, law reform processes, the drafting of statutes, statutory interpretation, various aspects of the-civil and criminal procedure including the role of juries, access to justice, the court structure, the appointment of judges and composition of the judiciary, and the structure of the legal profession. ${ }^{6}$ Atiyah and Summers compared each of those aspects of the English and American legal systems and others in detail.

The focus of this collection is on the interplay between form and substance in the law of obligations, including legal and equitable doctrines, judicial reasoning, the drafting of statutes, statutory interpretation, and private law theory.

\section{False Appearance and Inner Truth}

The form and substance dichotomy that is most familiar to private lawyers is the distinction between what Andrew Burrows describes in Chapter 2 as 'false appearance and inner truth. ${ }^{7}$ In this context, the form and substance dichotomy

\footnotetext{
${ }^{4}$ Atiyah and Summers, above n 1, 19-21 (on the impossibility or impracticability of a legal system that eschews either form or substance entirely) and 5 (on the contrasting visions of law). Atiyah and Summers (ibid 411-15) provide a more detailed account of differences between the formal and substantive visions of law in their concluding chapter.

${ }^{5}$ ibid, chs 8 and 9 (on contrasting theories of law).

${ }^{6}$ Atiyah and Summers, ibid 411, suggested that these factors 'mutually reinforce each other', but were careful not to make any claims about the existence of any identifiable causal connections (ibid 410-11). It has been suggested that the relationship between the institutional features of the two legal systems and their respective levels of formality might be better described as symbiotic, rather than causal: C Osakew, 'Rethinking the Communion Between the Common Laws of England and the United States' (1988) 82 Northwestern University Law Review 855. Cf MT Sigillito, 'Book Review' (1990) 34 St Louis University Law Journal 389.

${ }^{7}$ A Burrows, 'Form and Substance: Fictions and Judicial Power', this volume, ch 2, text following $\mathrm{n} 8$
} 
is invoked to justify looking beyond a chosen legal form to the true nature of a transaction or relationship in order to ensure that it has the consequences, either as between the parties or in the public interest, that it ought to have. Pey Woan Lee notes in Chapter 14 that transactions may be 'recharacterised' in order to prevent the avoidance of the legal incidents of a particular category of transaction or relationship at common law, or to prevent the avoidance of the consequences of a statutory regime. ${ }^{8}$ In this context substance is preferred to form where the form of a transaction or relationship is seen as artificial and the substance is considered to reflect the underlying reality of the situation. Whether transactions and relationships should be recharacterised is a familiar question in relation to employment, leases, trusts, mortgages and charges.

Looking more broadly at the category of false appearance and inner truth, substance is preferred to form in a number of different situations, and those situations can be classified in different ways. In Chapter 3, Birke Häcker distinguishes between the category of cases in which content prevails over name (such as employee/independent contractor and lease/licence), the broader category of cases in which legal substance prevails over factual appearance (including sham transactions and cases in which the equitable remedy of rectification is granted), and cases in which economic substance prevails over legal form. ${ }^{9}$ Häcker's economic substance/legal form category is exemplified by the understanding of contractual penalties adopted by the High Court of Australia in Andrews $v$ Australia and New Zealand Banking Group Limited, ${ }^{10}$ in which a contractual provision can constitute a penalty - even if it is not triggered by a breach of contract - if 'as a matter of substance' it is collateral to a primary stipulation, on the failure of which it imposes an additional detriment to the benefit of the other party. ${ }^{11}$

Within the broad category of form and substance in the sense of appearance and underlying truth, a more basic distinction can be drawn between the form and substance of legal transactions and legal relationships on the one hand and the form and substance of legal doctrines and judicial reasoning on the other. As we see in this volume, the notion of form and substance as appearance and underlying truth is not distinct from the notion of form and substance in the sense of rules and reasons. On the contrary, the two conceptions are heavily intertwined. The essential reason for this is that whether a transaction, relationship or legal doctrine should be understood or treated differently from its surface appearance is not

\footnotetext{
${ }^{8} \mathrm{PW}$ Lee, 'Form, Substance and Recharacterisation', this volume, ch 4.

${ }^{9}$ B Häcker, “Substance Over Form”: Has the Pendulum Swung Too Far?', this volume, ch 3.

${ }^{10}$ Andrews v Australia and New Zealand Banking Group Ltd [2012] HCA 30, (2012) 247 CLR 205 [10], contra Cavendish Square Holding BV v Makdessi; ParkingEye Limited v Beavis [2015] UKSC 67, [2016] AC 1172 [42]; see further Häcker, above n 9, text accompanying nn 93-97.

${ }^{11}$ See, however, B McFarlane, 'Form and Substance in Equity', this volume, ch 9, text accompanying nn $27-28$ on the limits of the notion that the court can look beyond the form adopted by the parties in this context.
} 


\section{Andrew Robertson and James Goudkamp}

simply a factual question of its inner truth or reality, but is an issue that requires consideration of normative questions of justice between the parties and the social and economic consequences of different characterisations.

\section{A. Recharacterising and Adjusting Transactions and Relationships}

The legal and equitable processes of looking beyond the name, form or appearance of a legal transaction or relationship encompass wholesale recharacterisations as well as more limited adjustments such as those made through the doctrine of rectification. A foundational question in this context is what constitutes the 'substance' that is to be preferred to the legal form. As Ben McFarlane notes in Chapter 10 , the relevant equitable maxim is sometimes expressed as 'equity looks to the substance rather than the form' and sometimes as 'equity looks to the intent rather than the form. ${ }^{\prime 2}$ Clearly party intent is the determining criterion in many instances. In such instances the courts are generally not concerned with the transactional form or form of words intended by the parties but with the rights and obligations they intended to create. In this respect, as Pey Woan Lee observes in Chapter 4, the courts tend to apply formal criteria in order to determine the substance of a transaction. Whether and when a transaction should be recharacterised, however, raises questions of substance in the sense of considerations of justice and community welfare. ${ }^{13}$ That is because recharacterisation raises normative questions about matters such as the implications of the avoidance - or inappropriate invocation of the common law incidents of particular categories of relationship, and the appropriateness of constraining party autonomy. ${ }^{14}$ Lee argues in Chapter 4 that in some instances these questions of substance need to be more openly acknowledged and explicitly addressed in recharacterisation cases. In her analysis of this topic Lee illustrates the deep and important connection between the two conceptions of form and substance.

Another strong example of the connection and interplay between the two kinds of form and substance (appearance/reality and rules/reasons) is provided by the decision of the English Court of Appeal in Shell UK Ltd $v$ Total UK Ltd, which is subjected to sustained critical analysis in three chapters in this volume. ${ }^{15}$ The court in that case held that the beneficial owner of property could recover damages for economic loss that is consequent upon physical damage to that

\footnotetext{
${ }^{12}$ B McFarlane, 'Form and Substance in Equity', this volume, ch 9, fn 2, citing J Heydon, M Leeming and P Turner (eds), Meagher, Gummow and Lehane's Equity: Doctrines and Remedies, 5th edn (Sydney, LexisNexis, 2015) para 3.145.

13 ibid.

${ }^{14}$ ibid.

${ }^{15}$ [2010] EWCA Civ 180, [2011] QB 86 ('Shell v Total'), discussed by B Häcker, above n 9; McFarlane, above n 12 and W Swadling, 'In Defence of Formalism', this volume, ch 5.
} 
property caused by the defendant's negligence, provided the trustee is joined in the proceedings. In doing so, the court departed from the general rule that only the legal owner or a person with a possessory interest in property can recover damages for loss caused by the destruction of or damage to that property. The court furthered the erosion of the general rule against liability for pure economic loss in negligence. It also departed from the foundational notion that a beneficiary under a trust does not have a right to the trust asset itself, but only rights against the trustee (which may affect third parties who deal with the trustee). ${ }^{16}$ The court was influenced by a concern that legal rules must not be-stand in the way of 'practical justice', noting that it would be 'legalistic' to deny a right to recovery to the 'real owner' of the property, and that it 'should not be legally relevant' that the "real" owner' had chosen to vest legal title in another company. The court concluded that it 'it would be a triumph of form over substance to deny a remedy to the beneficial owner of property when the legal owner is a bare trustee for that beneficial owner.' ${ }^{17}$

The court's concern to do 'practical justice' in Shell $v$ Total led to a development which was incompatible with the concept of the trust as conventionally understood. Substance in the shape of 'real ownership' (underlying truth) and 'practical justice' (reasons) prevailed over recognised legal forms (rules and concepts), and what was taken to be a 'legalistic' (formalistic) understanding of the law. If one accepts the force of the widespread criticism of the decision in Shell $v$ Total, ${ }^{18}$ then it provides a good example of what Atiyah and Summers called 'substantivistic' reasoning: a favouring of substance (in the sense of both underlying reality and a loose sense of justice) over form (in the sense of both appearance and rules) which may be considered excessive when judged by the standards of the jurisdiction in which it was made. ${ }^{19}$ The analysis of Shell $v$ Total by Häcker, McFarlane and Swadling in this volume suggests that the decision illustrates the dangers of too great a willingness to dismiss a concern with form and the application of settled principles as 'legalistic' and 'formalistic'. Doing so in this case, that analysis suggests, not only resulted in the distortion of legal forms, but also in inadequate consideration of the significant issues of substance raised by the case. That an English appellate court could be accused of such insufficient attention to form in an important case is clearly noteworthy in view of Atiyah and Summers' thesis, although the criticism the decision has attracted in this volume and elsewhere is itself noterorthy as a countervailing indicater.

\footnotetext{
${ }^{16}$ J Edelman, 'Two Fundamental Questions for the Law of Trusts' (2013) 129 LQR 66, 85; Swadling, above n 15, text accompanying nn 47-60; McFarlane, above n 12, Pt III.

17 [2010] EWCA Civ 180, [2011] QB 86 [143]. See also at [132].

${ }^{18}$ See, eg, PG Turner, 'Consequential Economic Loss and the Trust Beneficiary' (2010) 69 CLJ 445, 446 ('This holding does a disservice to tort and trust law'), K Low, 'Economic Title and Economic Loss' (2010) 126 LQR 507 and the works cited by Häcker, above n 9, fn 139.

${ }^{19}$ Atiyah and Summers at 30-31.
} 
That critical response points to the strength of the continuing commitment to form in English legal culture.

\section{B. Recharacterising Legal Doctrines and Judicial Reasoning}

Points of contrast between the false appearance and inner truth of legal reasoning provide the primary focus of Andrew Burrows' Chapter 2. ${ }^{20}$ Burrows' concern is with legal fictions: artificial concepts or lines of reasoning used by judges which obscure their true motivations or reasons. Burrows suggests that fictions in judicial reasoning conceal or underplay the power that judges exercise, but argues that judges ought to embrace rather than fear acknowledgment of that power. Open recognition of the fact that judges make law, for example, provides an opportunity for that power to be explained, rationalised and used carefully in light of the relationship between the judiciary and the legislature. The eradication of fictions forces judges to confront difficult questions, but those questions must, Burrows argues, be addressed in order to promote rationality and transparency in the law. It is on this basis that Burrows celebrates the recent decision of the Supreme Court of the United Kingdom in Patel v Mirza. ${ }^{21}$ In that case, the Court held by a narrow majority that, in asking whether the defence of illegality applies to a claim in unjust enrichment, it is necessary openly to discuss and balance the competing policy considerations that weigh in favour of, and against, the application of the defence.

Another overlap is encountered between the two notions of form and substance (appearance/reality and rules/reasons) in relation to questions of taxonomy. As Andrew Robertson argues in Chapter 11, notions of form and substance underlie the standard 'lumping' and 'splitting' taxonomical analyses and disputes. ${ }^{22}$ A conventional taxonomic argument is that the form of the law does not reflect some underlying truth, either because what is understood as a single doctrine is in fact more complex and deals with a number of different types of case which would better be understood separately or, conversely, two separate doctrines operate in circumstances that are so closely analogous that they are in substance doing the same work or producing inconsistent results in analogous cases. This may be seen as an issue concerning form and substance in the sense of appearance and underlying reality. But it is also fundamentally a question about rules and reasons, as Chapter 11 shows, because taxonomic issues ultimately turn on the purposes served by the doctrines in question, and on the unity or disunity of the issues of justice and policy in the different categories of case.

\footnotetext{
${ }^{20}$ Burrows, above $\mathrm{n} 7$.

${ }^{21}$ [2016] UKSC 42, [2017] AC 467.

${ }^{22}$ A Robertson, 'The Form and Substance of Equitable Estoppel', this volume, ch 11.
} 


\section{Rules and Reasons}

\section{A. The Relationship between Rules and Rationales}

One of the dominant scholarly methodologies in the law of obligations in the common law world is interpretive: its aim is to understand the law at a deep level, to reveal the rationales and purposes underlying the law and to explain why the law is as it is. An interpretive theory of the common law is generally tested through some combination of the following criteria: fit (consistency between the theory and established legal rules and the outcomes of the cases), coherence (the extent to the theory presents the law as coherent or reveals an 'intelligible order' in the law), justification (the extent to which the theory presents the law in its best normative light, and shows it to be consistent with whatever normative influences there are or should be on the law, such as notions of right and wrong or economic efficiency), and fidelity (consistency with the reasons given by the judges in the cases). ${ }^{23}$ That broad interpretive methodology covers a wide range of different scholarly approaches because the elements can be combined in different ways, with differing levels of weight accorded to the different criteria, and in some instances particular criteria given no weight at all. ${ }^{24}$

An interesting question raised by the contributions to this volume by Liam Murphy and Robert Stevens is the relationship between form and substance, in the sense of rules and reasons broadly understood, in an interpretive theory of law. For Robert Stevens, form controls substance. ${ }^{25}$ Following Weinrib, ${ }^{26}$ Stevens argues that the bilateral form of private law imposes strict limits on the kinds of reasons that can justify it and to which, consequently, judges should be permitted to make recourse. The distinguishing feature of private law duties, Stevens contends, is that they are owed to other people who have control over them. While the power to sue is usually an aspect of that control, Stevens argues that is not the defining feature of a private law right because it is neither unique to private law nor a necessary feature of a private law right/duty relationship. Rather, the distinguishing feature of a private law duty is the control enjoyed by the rightholder in the form of a power to consent to non-performance or release the obligor from the duty. Since the private law right/duty relationship is in this way bilateral at is core, the reasons that justify those legal relations must also be bilateral, in the sense that they must apply equally to both parties. For Stevens, therefore, one-sided arguments (such as the need to deter the defendant or the desire to see that the claimant is compensated for his or her loss) cannot be understood to

\footnotetext{
${ }^{23}$ SA Smith, Contract Theory (Oxford, Oxford University Press, 1993) 7-13; Murphy, 'The Formality of Contractual Obligation', this volume, ch 7.

${ }^{24}$ A Robertson, 'Rights, Pluralism and the Duty of Care' in D Nolan and A Robertson (eds), Rights and Private Law (Oxford, Hart Publishing, 2012) 437-9.

${ }^{25} \mathrm{R}$ Stevens, 'Private Law and the Form of Reasons', this volume, ch 6.

${ }^{26}$ EJ Weinrib, The Idea of Private Law (Cambridge, MA, Harvard University Press, 1995).
} 


\section{Andrew Robertson and James Goudkamp}

underlie private law rights and duties: if they do not apply equally to both parties then they are not 'right-shaped reasons'. The form of private law, on this view, dictates the kinds of reasons of substance that can be understood to justify it.

A fundamentally different understanding of the relationship between form and substance or rules and reasons in interpretive legal theory is adopted by Liam Murphy in Chapter 6 . Murphy's focus is content formality, which is the extent to which a rule or reason is - or can be seen to be - shaped by underlying concerns of substance, such as justice or policy. If a legal rule has low content formality, then its form clearly does not control the reasons of substance that can be understood to underlie it. Atiyah and Summers suggest that a rule has high content formality if its content is shaped by fiat - ie, somewhat arbitrary - or is 'under-inclusive or over-inclusive in relation to its objectives. ${ }^{27}$ The rule that one must drive on the left or right-hand side of a road has high content formality because its content is chosen arbitrarily: what matters is that there must be a rule, rather than which side is chosen. ${ }^{28}$ Atiyah and Summers also cite the requirement that a will must be attested by two witnesses as an example of a highly formal rule, not because of its arbitrariness, but because it is over-inclusive. The purpose of the rule is to ensure that a will was signed by the testator, but a will may be struck down by the rule even though there is other reliable evidence that it was signed by the testator. ${ }^{29}$ The Australian statutory prohibition on misleading or deceptive conduct in trade or commerce, by way of contrast, has very low content formality because its content is shaped more or less entirely by reasons of substance. ${ }^{30}$ The rule prohibits the very kind of conduct that is its purpose to prevent.

Murphy suggests that a rule can be understood to have high content formality if it does not state its rationale, and can be understood as more substantive the more it makes clear its purpose. On that basis, Murphy argues that contract law as a whole has high content formality because it is instrumental, and the purposes it pursues are not evident in the rules and principles of contract law. On its face, contract law seems to be based on the idea that the law of contract enforces promises and agreements because people ought, as a matter of right and wrong, to keep their promises and agreements. But Murphy's analysis proceeds on the premise that there are no natural promissory rights and duties. Rather, Murphy suggests that promissory morality is dependent on the existence of a conventional social practice requiring the keeping of promises. If that premise is accepted, then the best understanding of the purpose of contract law is that it is to promote the beneficial social practices of keeping promises and agreements. Since that purpose is

\footnotetext{
${ }^{27}$ Atiyah and Summers, above n 1, 13.

${ }^{28}$ ibid.

${ }^{29}$ As Kennedy, above n 2, 1695 notes, some over-inclusion and under-inclusion inevitably result from the use of a rule rather than a standard, and 'are the price of avoiding the potential arbitrariness and uncertainty of a standard'.

${ }^{30}$ Australian Consumer Law, s 18; see J Paterson and E Bant, 'Misrepresentation, Misleading Conduct and Statute through the Lens of Form and Substance', this volume, ch 17.
} 
not evident in even the most fundamental principles of contract law, contract law as a whole must be understood to have a high level of content formality.

The flexibility of interpretive legal methodology is exemplified by the fact that it is followed by two groups of scholars who hold fundamentally different, perhaps even ultimately irreconcilable, understandings of law and approaches to legal scholarship. In Chapter 5, Dan Priel distinguishes two different kinds of 'formalism' in obligations scholarship: conceptualism and doctrinalism. ${ }^{31}$ Doctrinalism is an approach which begins with the cases and seeks to identify structure, coherence and general principles by way of induction. Priel suggests that this approach is 'formalist' in the sense that it places faith in the development of dispositive legal categories. ${ }^{32}$ Conceptualism, in contrast, begins with relations between individuals and develops universal ideas about law on the basis of reason. Conceptualism is ultimately grounded in notions of natural law and takes relations between individuals as its governing forms. While doctrinal scholarship rarely drills down to deep jurisprudential levels, most doctrinal scholarship is consistent with a positivist understanding of law. Priel's analysis of the tenets, techniques, strengths, weaknesses, points of connection and divergences between these two kinds of 'formalism' offers a deep and potentially very productive understanding of the dominant forms of contemporary obligations scholarship.

\section{B. The Form and Substance of Equity}

The maxim that 'equity looks to the substance rather than the form' is potentially misleading to the extent that it suggests that the common law is unconcerned with substance and to the extent that it indicates that equity is unconcerned with form. As Ben McFarlane observes in Chapter 9, courts look to the substance of transactions for the purpose of determining the parties' common law rights as well as the application of equitable principles. Moreover, McFarlane argues, form is vitally important in equity, and in understanding equity. Equity may look beyond the form of a trustee's ownership to recognise the beneficiary as the 'true owner', but, McFarlane's analysis suggests, the notion that the beneficiary's 'ownership' can be equated with legal ownership is dangerously misleading, as exemplified by Shell $v$ Total. McFarlane argues that it helps us to understand equity to see that it commonly operates by controlling the enforcement or acquisition of legal rights. Thus, a beneficiary's right under a trust is not best understood as a form of ownership, but as a right against the trustee's right. ${ }^{33} \mathrm{McF}$ arlane does not argue that this is all equity does, nor that the common law does not control the acquisition and enforcement of rights, but that many equitable rules operate in this way, that it

\footnotetext{
${ }^{31}$ D Priel, 'Two Forms of Formalism', this volume, ch 8.

${ }^{32}$ ibid, text preceding fn 26.

${ }^{33}$ B McFarlane and R Stevens, 'The nature of equitable property' (2010) 4 Journal of Equity 1.
} 
is consistent with the notion of equity as a supplement to the common law, and that paying attention to this form helps us to understand equity as a second order system.

Of course, as Man Yip reminds us in Chapter 10, it is in the very nature of equity to favour reasons over rules in particular instances. ${ }^{34}$ Equity developed as a substance-driven response to the restrictive rules of the common law, and even in its contemporary, more rule-based form routinely calls for direct consideration of underlying issues of justice and questions of right and wrong. The primary vehicle for consideration of issues of substance in equity is, of course, the notion of conscience. In Chapter 10-Man Yip argues that English equity has, in recent years, taken a turn away from formality and towards substance. She identifies symptoms of that trend (the treatment of precedent, the rise of discretion and increased sensitivity to context) and suggests some causes (increasing diversity of fact situations, rising complexity and a turn to pragmatism). She identifies two different models by which considerations of substance are given priority in recent equity jurisprudence: the first is the 'open discretion model' which involves a 'range of factors' or 'in the round' analysis in the first instance, the second involves the softening of a primary rule by way of a 'residual discretion' which allows the court to do justice on the facts of the particular case.

One of the symptoms of the turn to substance in English equity identified by Man Yip is the role played by precedent in judicial reasoning: the approach taken to conflicting authorities, the extent of deference to precedent and the interaction between precedent on the one hand and justice and policy on the other. For Atiyah and Summers, a significant dimension of form and substance in legal reasoning was the treatment of precedent, a topic to which they devoted considerable attention. ${ }^{35}$ They observed that through a variety of accepted practices and techniques, American judges enjoyed much greater powers - and had much greater willingness - to disregard, overrule and evade precedent than English judges. English judges generally took pains to reconcile, explain and distinguish conflicting authorities ${ }^{36}$ and, of course, the House of Lords considered that it was bound by its own decisions until 1966. Perhaps most tellingly, Atiyah and Summers noted that English judges were more inclined on a day-to-day basis to be more deferential to colleagues whose judgments were not binding on them even if they disagreed with them. ${ }^{37}$ It is noteworthy, then, that Man Yip identifies a greater willingness in the Supreme Court of the United Kingdom to resolve difficult questions by direct reference to the underlying issues of substance without feeling compelled to reconcile and rationalise conflicting lines of authority. ${ }^{38}$

\footnotetext{
${ }^{34}$ Man Yip, 'Modern Equity - At the Edge of Formal Reasoning?', this volume, ch 10.

${ }^{35}$ Atiyah and Summers, above $n 3_{\text {, }}$ ch 5 .

${ }^{36}$ ibid 129.

${ }^{37}$ ibid 127.

${ }^{38} \mathrm{Cf}$ the analysis offered by James Lee in his chapter in this volume of several decisions of the Supreme Court of the United Kingdom in the law of torts. We discuss Lee's chapter in the section below.
} 


\section{Form and Substance in the Law of Torts}

Atiyah and Summers touched on certain decisions in the law of torts but, by and large, did not engage with that branch of the law of obligations at any length. Several chapters in this volume, therefore, seek to apply the Atiyah and Summers' framework with a view to illuminating this area of private law. Jason Neyers in his chapter focuses on the tort of deceit and, in particular, the requirement that the plaintiff suffer actionable damage. He lays siege to a loss-based understanding of that tort, that is, one that comprehends the idea of damage as meaning that the plaintiff has been made factually worse off, and contends that that account of the damage element is animated by a highly formal assessment of the relevant cases. His overarching thesis is that ' $\mathrm{t}$ ] his formalistic view has prevented English scholars from providing compelling justifications for the results of leading deceit cases on damages and thereby from unearthing the core principle animating the tort. ${ }^{39}$ Superior to the traditional loss-based account of deceit in terms of its power to explain leading cases in the field, Neyers contends, is the notion that the damage element of the tort requires 'the non-consensual dispossession of a right previously held by the claimant. ${ }^{40}$ Although Neyers grapples only with the tort of deceit, it is doubtful that his understanding of the concept of damage is meant to be confined to that tort. It may well be that his analysis sheds light on how the concept of damage is to be understood in relation to all torts of which damage is an ingredient.

James Goudkamp and Eleni Katsampouka in Chapter 14 engage with the jurisdiction to award punitive damages, which jurisdiction is either available only in the context of tort law or is predominantly enlivened in connection with claims in tort, depending on the legal system with which one is concerned. Atiyah and Summers singled out the decision of the House of Lords in Rookes $v$ Barnard ${ }^{41}$ as powerful evidence in support of their claim that English law is excessively formal. In that case, Lord Devlin controversially held that precedent required that the award of punitive damages be limited to just three categories of case (ie, cases where the defendant was a government servant and, acting in that capacity, engaged in oppressive, arbitrary or unconstitutional conduct, instances where the defendant had a profit motive, and situations where statute mandated the availability of punitive damages). Rookes certainly exemplifies formalistic reasoning. It does so partly because of Lord Devlin's extensive reliance on, and fine-grained analysis of, precedent but more fundamentally because it denies the availability of punitive damages in all cases that do not fall within one of the identified categories, irrespective of whether the reasons for awarding punitive damages (which the court identify as being punishment and deterrence) suggest that an award should

\footnotetext{
${ }^{39} \mathrm{~J}$ Neyers, 'Form and Substance in the Tort of Deceit', this volume, ch 13.

${ }^{40}$ ibid, text following $\mathrm{n} 7$.

41 [1964] AC 1129.
} 
be made. Goudkamp and Katsampouka build on Atiyah and Summers' analysis of this topic with reference to the contemporary law. Goudkamp and Katsampouka's essential concern is not to make any particular claims regarding how the law of punitive damages should be structured but to facilitate understanding of the existing law in this regard by scrutinising it through the prism of Atiyah and Summers' work. In the spirit of Atiyah and Summers' project, they examine the position in England and the US, but also in Australia and Canada. Their conclusion is that, in so far as the award of punitive damages is concerned, Atiyah and Summers' thesis that English law is dominated by formal reasoning while in the US substantive reasoning prevails holds good, although the picture is not as clear as it was at the time that Atiyah and Summers were writing. This is partly because judges at the ultimate appellate level in England have, since the turn of the twenty-first century, shown increased willingness to shape the law of punitive damages by reference to the rationales for the award. ${ }^{42}$

James Lee's chapter ${ }^{43}$ analyses the balance between form and substance in a series of decisions of the Supreme Court of the UK in several topics in the law of torts. His primary focus is on two fields in which the Court has been particularly active in recent years: the duty of care element of the tort of negligence and vicarious liability. Interestingly, Lee's analysis reveals the employment of different types of reasoning across these areas. In relation to duty of care, Lee points out that recent decisions have (at least) marginalised or retreated from the Caparo test, ${ }^{44}$ the third stage of which explicitly calls for consideration of substantive reasons. ${ }^{45}$ Instead, the Supreme Court has emphasised in several recent decisions ${ }^{46}$ the overriding importance of allegiance to precedent. The basic idea underpinning the cases concerned is that it is illegitimate to ask de novo in each and every situation whether policy favours or militates against the recognition of a duty of care and to recognise or deny the existence of a duty accordingly. Instead, the starting point is whether an existing case settles the position. It is only in truly novel matters that it is permissible, on this approach, to enquire as to what policy demands. Lee emphasises that the Supreme Court's recent jurisprudence on duty of care plainly contrasts radically with that in relation to vicarious liability. In relation to the latter doctrine, the Supreme Court ${ }^{47}$ has extended relentlessly the circumstances

\footnotetext{
${ }^{42}$ See, in particular, Kuddus v Chief Constable of Leicestershire [2001] UKHL 29, [2002] 2 AC 122.

${ }^{43} \mathrm{~J}$ Lee, 'Trends in Tort Law: Bad Form and Addictive Substance?', this volume, ch 12.

${ }^{44}$ Caparo Industries Plc v Dickman [1990] 2 AC 605.

${ }^{45}$ See further A Robertson, 'Justice, Community Welfare and the Duty of Care' (2011) 127 LQR 370, 'On the Function of the Law of Negligence' (2013) 33 OJLS 31 and 'Policy-Based Reasoning in Duty of Care Cases' (2013) 33 Legal Studies 119.

${ }^{46}$ Michael v Chief Constable of South Wales Police [2015] UKSC 2, [2015] AC 1732; Robinson v Chief Constable of West Yorkshire [2018] UKSC 4, [2018] AC 736; Darnley v Croydon Health Services NHS Trust [2018] UKSC 50; [2018] 3 WLR 1153.

${ }^{47}$ Various Claimants v Catholic Child Welfare Society [2012] UKSC 56, [2013] 2 AC 1; Cox v Ministry of Justice [2016] UKSC 10, [2016] AC 660; Armes v Nottinghamshire County Council [2017] UKSC 60, [2018] AC 355; Mohamud v Wm Morrison Supermarkets Plc [2016] UKSC 11, [2016] AC 677.
} 
in which vicarious liability arises by reference to the perceived reasons for that principle of liability and, further, has placed policy considerations front and centre in the determination of whether vicarious liability should be imposed. The reason why the Supreme Court has employed fundamentally different modes of reasoning in these two important (and closely related) parts of tort law more or less simultaneously is unclear, although it is doubtful that the difference is due to differently constituted benches.

\section{Form and Substance in Legislation}

Atiyah and Summers regarded statutes as inherently formal. ${ }^{48}$ Whereas judges must give reasons for their decisions from which the rationale for the rule in issue may be discerned, a statute is simply a series of commands. Those commands must be faithfully applied and take precedence automatically (subject to constitutional principles) over other sources of law and other reasons that legal actors may have for action. Historically, statute has played a relatively unimportant role in the law of obligations, with the great bulk of the rules that constitute this part of the law having been created by judges. This pattern, however, is changing, with legislation having an increasingly significant impact on private law rights and duties. As such, one may expect that, generally speaking, the rise of statute would be gradually rendering the law of obligations increasingly formal.

Although there is an inherent formality to statutes, the degree of formality in statute law is neither uniform nor straightforward, for a number of reasons. In the first place, the level of content formality varies greatly. While some statutes exhibit high content formality, others, as noted earlier, are manifestly substantive in content. This is a recurring theme of Jeannie Paterson and Elise Bant's chapter. ${ }^{49}$ Paterson and Bant compare the English Misrepresentation Act 1967 (UK) with the statutory prohibition of misleading conduct in Australia. They emphasise that the English statute is far more narrow and prescriptive than the Australian legislation, and this has significant consequences for its interpretation and therefore, arguably, its effectiveness. They write that ' $t$ the prescriptive expression of the Misrepresentation Act has encouraged the English judicial proclivity for formal reasoning. ${ }^{50}$ By contrast, they contend that legislation such as the Australian prohibition on misleading conduct, which draws on 'open-textured standards', prompts a more substantive approach to interpretation in which the courts construe the legislation with direct reference to its purposes. Paterson and Bant examine the judicial responses to contracting parties' attempts to contract around the English and Australian legislation, and this provides an illuminating contrast between the two different styles of legislative drafting and interpretation.

\footnotetext{
${ }^{48}$ Atiyah and Summers, above n 1, 96-98.

${ }^{49}$ Paterson and Bant, above $\mathrm{n} 30$.

${ }^{50} \mathrm{ibid}$, text following n 142 .
} 


\section{Andrew Robertson and James Goudkamp}

Secondly, the formality of statutes is in some instances diminished by provisions that expressly allow or even require substantive considerations to be taken into account in their interpretation. Such provisions sometimes govern the interpretation of particular statutes, ${ }^{51}$ and are sometimes promulgated as general principles of statutory interpretation. An example of the latter is the provision enacted by the Australian Parliament that requires 'the interpretation that would best achieve the purpose or object' of an act 'to be preferred to each other interpretation., 52 It sits alongside a provision allowing courts to have recourse to extrinsic material for certain specified purposes. ${ }^{53}$ Ben Chen and Jeff Gordon explain in Chapter 16 how the enactment of those provision ushered in a markedly less formal, more contextualist approach to statutory interpretation in Australia.

Thirdly, statutes and the common law are fundamentally interlinked at a number of levels. ${ }^{54}$ For example, a significant proportion of the common law comprises judge-created rules that gloss statutes and tell us how they are to be understood (so called 'statutory common law'). Some statutes 'preserve' the common law, which presents issues of formidable complexity, ${ }^{55}$ such as whether the relevant common law is thereby ossified as at the date of the statute and rendered incapable of further development. Further, many statutes would simply be unintelligible considered in isolation but anticipate, like equity, the existence of a substantial body of common law principles. Such statutes are inextricably linked with the common law. Even so called 'codes' are, as Ben Chen and Jeff Gordon observe ${ }^{56}$ not written on a tabula rasa. Chen and Gordon argue that the displacement of the common law by legislation is not binary but continuous, and may best be understood by reference to the idea of a 'displacement continuum', with complete codes at one end, modification or supplementation in the middle, and minimal displacement at the other end. ${ }^{57}$ On the relationship between statutes and the common law, it should finally be noted that there is, of course, a profound and difficult question of the extent to which the common law should be adapted in view of a relevant statute. ${ }^{58}$ On one view, the superiority of statute as a source of law, both authoritatively but also increasingly in terms of its importance and ubiquity, requires that the judge-made law evolve in a manner that is coherent with statute.

\footnotetext{
${ }^{51}$ See, eg, Murphy, above n 23, text accompanying $\mathrm{n} 9$.

${ }^{52}$ Acts Interpretation Act 1901 (Cth), s 15AA ('In interpreting a provision of an Act, the interpretation that would best achieve the purpose or object of the Act (whether or not that purpose or object is expressly stated in the Act) is to be preferred to each other interpretation').

${ }^{53}$ Acts Interpretation Act 1901 (Cth) s $15 \mathrm{AB}$.

${ }^{54}$ For valuable analysis, see A Burrows, 'The relationship between common law and statute in the law of obligations' (2012) 128 LQR 232.

${ }^{55}$ For illuminating discussion, see R Munday 'Legislation that would "preserve" the common law: the case of the (hearsay) declaration of intention' (2008) 124 LQR 46.

${ }^{56} \mathrm{~B}$ Chen and J Gordon, 'Interpretive Formalism in the Law of Obligations: Thirty Years after Form and Substance', this volume, ch 16, text accompanying $\mathrm{n} 79$.

${ }^{57} \mathrm{ibid}$, text accompanying nn $62-89$.

${ }^{58}$ The classic analysis of this issue is PS Atiyah, 'Common Law and Statute Law' (1985) 48 MLR 1.
} 
A fourth complicating factor is that judges are the ultimate arbiters of what statutes mean, with the result that different approaches to statutory interpretation can render statutes either more or less formal. For example, a highly formal approach to construction concentrates simply on the text, whereas a more substantive approach takes account of the purposes and policies underlying the statute, which may even be given primacy over the words used..$^{59}$ As Atiyah and Summers note, those purposes can be gleaned or inferred from the text itself, or identified through other sources such as legislative history. ${ }^{60}$ This fourth consideration is the primary focus of Ben Chen and Jeff Gordon's chapter in this volume, which compares approaches to statutory interpretation in Australia and US. ${ }^{61}$

At the risk of oversimplifying Chen and Gordon's nuanced analysis, their overarching thesis is that while the Australian approach to statutory interpretation has become significantly most substantive, the approach followed in the US has become markedly more formal. Chen and Gordon note the observation made by Lord Scarman in a lecture in Melbourne in 1980 that the High Court of Australia was 'more English than the English' in its approach to statutory interpretation. ${ }^{62}$ Legislative reform followed almost immediately and the courts subsequently developed a more contextual approach. ${ }^{63}$ Patrick Atiyah speculated in 1992 that Australia might occupy 'a position somewhere between England and America' in the level of formality of its legal system. ${ }^{64}$ Chen and Gordon argue that, in the realm of contract interpretation, Australian law now oscillates between textualism and contextualism, in contrast to a strong trend in favour of textualism in the US. In the field of statutory interpretation, Chen and Gordon argue, Australian law has become firmly contextualist, while Justice Scalia has led the US courts in a strongly textualist direction.

The complexity of the interaction between the common law and statute, and the importance of being attentive to that interaction, is emphasised by Mark Leeming's chapter in this volume ${ }^{65}$ Leeming focuses on three occasions where legislation and the common law coalesce (or contrast) with each other. These are the availability or otherwise of apportionment for contributory negligence in claims for breach of contract, the law of punitive damages and the different approaches to the interpretation of judgments and statutory text, and the statutory modification in Australia of the concept of unconscionable conduct. The first of these issues has particular

\footnotetext{
${ }^{59}$ Atiyah and Summers, above n 1, 100.

${ }^{60}$ ibid 15.

${ }^{61}$ Chen and Gordon, above n 56.

${ }^{62}$ ibid, text accompanying n 35, quoting L Scarman, 'Ninth Wilfred Fullagar Memorial Lecture: The Common Law Judge and the Twentieth Century - Happy Marriage or Irretrievable Breakdown?' (1980) 7 Monash Law Review 1.

${ }^{63}$ Chen and Gordon, above n 56, text following n 35.

${ }^{64}$ PS Atiyah, 'Justice and Predictability in the Common Law' (1992) 15 University of New South Wales Law Journal 448, 454 (noting that he was 'not sufficiently familiar with trends in Australian law today' to do more than speculate on the question).

${ }^{65} \mathrm{M}$ Leeming, 'Statute Law in the Law of Obligations: Dimensions of Form and Substance', this volume, ch 4. See, further M Leeming, The Statutory Foundations of Negligence (Sydney, Federation Press, 2019).
} 
relevance in the present context. In England, it has long been the law that damages in a claim for breach of contract cannot be reduced for contributory negligence unless the contractual duty concerned is one that requires the taking of reasonable care and a parallel obligation arises in the tort of negligence. ${ }^{66}$ The Court of Appeal arrived at this conclusion without reference to the statutory language of the Law Reform (Contributory Negligence) Act 1945, but in view of what it ultimately thought was a just and fair rule to adopt. ${ }^{67}$ By contrast, the High Court of Australia held in dramatic fashion ${ }^{68}$ that materially identical legislation in South Australia had no application to contractual claims with the result that, where a plaintiff had concurrent claims in tort and contract, the award in the contractual claim would be unaffected by any contributory negligence of which the plaintiff may be guilty. The High Court arrived at that conclusion following close attention to the legislative text. The difference between the judicial methodologies in England (more substantive) and Australia (more formal) is stark. One of Leeming's concerns is to rebut certain criticisms that have been made of the High Court's decision, which was promptly overturned by statutes enacted across Australia. He emphasises that the High Court's decision was an exercise in the interpretation of a statute and that the words of the statute were quite clearly directed at the position in tort and to tort alone.

\section{Conclusion}

The essays in this volume show that the form and substance dichotomy provides a productive frame of reference for studying the law of obligations. It allows illuminating comparisons to be drawn across time, between jurisdictions, between different subject areas and between different approaches to myriad factual, doctrinal and theoretical problems. Above all, this volume shows that form and substance are inextricably intertwined in the common law of obligations. Both form and substance are essential elements of legal reasoning in this area of the law, and dangers lie in the neglect of either. Strong arguments are made in this book for favouring form over substance in some situations, and for choosing substance over form in others. This collection suggests that not only is it 'possible to be formalist in one way and substantivist in another', as Kit Barker observes in his concluding chapter, ${ }^{69}$ but it is also necessary. Just as common law method requires frequent movement back and forth between fact and value, it also requires frequent movement back and forth between form and substance. That movement between form and substance is a vital element of the dynamism of the common law of obligations.

\footnotetext{
${ }^{66}$ For discussion, see J Goudkamp, 'The Contributory Negligence Doctrine: Four Commercial Law Problems' [2017] Lloyd's Maritime and Commercial Law Quarterly 213, 219-228.

${ }^{67}$ Forsikringsaktieselskapet Vesta $v$ Butcher [1989] AC 852.

${ }^{68}$ Astley v Austrust Ltd [1999] HCA 6, (1999) 197 CLR 1.

${ }^{69}$ Barker, above $\mathrm{n} 3$.
} 